\title{
11. Media hypes and public opinion
}

\author{
Human interest frames and hype fatigue \\ Audun Beyer and Tine Ustad Figenschou
}

\author{
Vasterman, Peter (ed.), From Media Hype to Twitter Storm. News Explo- \\ sions and Their Impact on Issues, Crises, and Public Opinion. Amsterdam \\ University Press, 2018 \\ DOI: $10.5117 / 9789462982178 / \mathrm{CH} 11$
}

\begin{abstract}
This chapter investigates how news audiences perceive media hypes, a topic largely unexplored in extant studies of news hypes. It first elaborates on normative perspectives regarding how citizens should keep informed and relate to the news. Second, it analyses a survey study of a representative sample of the population on their evaluations of media performance during and in relation to a highly salient media hype. It explores how the audience evaluate media performance and what aspects of the hype coverage they emphasize. It finds that the public is overwhelmingly critical towards the media coverage, particularly on the scale (volume) and scope of the news hype, and perceived media bias.
\end{abstract}

Keywords: public opinion, survey, human interest, hype, media criticism

The study of media hypes has largely been concerned with the study of news content and news work, understood as the sociology of news organizations and news workers. From this literature, we already have important knowledge of what characterizes media hypes (see Vasterman, 2005; Elmelund-Præstekær \& Wien, 2008; Wien \& Elmelund-Præstekær, 2009): Media hypes tend to materialize suddenly as news waves triggered by some key event (Vasterman, 2005, 515-516). Further, some form of 'interaction between the media and social actors' characterizes media hypes according to Vasterman (Ibid.), meaning that this interaction itself becomes part of the hype, and thus receive substantial coverage as the hype unfolds across media outlets. However, what currently lacks in the literature concerning media hypes is the study of how such coverage affects public opinion and how news audiences perceive such hypes. This chapter contributes some 
theoretical perspectives concerning this relationship, discussed through empirical evidence that illuminates the question of how publics evaluate media hypes. ${ }^{1}$

First, we introduce the concepts of media hypes and public opinion with reference to a normative perspective of what news should be. Throughout the history of media research the question of what publics actually need to know to be considered informed citizens has been highly salient (Christians et al., 2009). While there is in no way a clear consensus on this important question, different perspectives highlight different roles for publics, and accordingly, they put different demands on what journalism should be. In the present chapter, we discuss media hypes with reference to Zaller's (2003) distinction between the fullnews standard, and the burglar alarm standard of news quality, while also making reference to Michael Schudson's (1998) notion of the monitorial citizen. Secondly, we present a case concerning a highly salient news media hype from Norway, and a survey study asking a representative sample of the population of their evaluations of media performance during and in relation to the media hype. Finally, we conclude with suggestions for future research concerning public opinion and media hypes, highlighting the need for normative perspectives to be included in discussions of this relationship.

\section{The quality of news and demands on citizens}

What do citizens need to know to be considered informed enough to participate in democratic societies? This question has probably been discussed for as long as the concepts of democracy, citizens, and public opinion has been around. Michael Schudson (1998) refers to Walter Lippmann when he concludes, that 'if democracy requires omnipotence and omniscience from its citizens, it is a lost cause' (Schudson, 1998: 310). On a general level, it is hard to disagree with this statement, but it does not necessarily follow a distinct view of the normative standard of news quality from such a general statement. Schudson's aim is not, however, to develop such a standard, but he introduces a concept that is later picked up by Zaller (2003), when he tries to envision a normative standard of news quality. This is the concept of the monitorial citizen, as opposed to the informed citizen. The monitorial citizen, says Schudson, 'engages in environmental surveillance more than information-gathering' (Schudson, 1998: 311). Schudson's point seems to be that most people do not need to proactively seek out information, but that this not means that they always will be inactive. Rather, they will be 
'poised for action if action is required' (Ibid.). Thus, it will be the task of the news media, and journalism, to get their attention in case action is needed.

In some ways this is the point of departure for John Zaller (2003) when he attempts to formulate a standard of news quality that is actually possible for both the news media to deliver, and for the public to be attentive to. Zaller starts out by arguing that the vast majority of scholars, including W. Lance Bennett and Thomas Patterson, seem to say that the quality of news should be judged by what he calls the full news standard (Ibid.: 110). The full news standard is a historically developed standard of news that, according to Zaller, is best viewed through several phases. In an early phase of American democracy, the view of citizens' roles was indeed very far from today, and this was also the case with the demands on news. For instance, Schudson argues that to be informed in the late 179os meant only to know who the candidates were and their character (Schudson, 1998: 72, as cited in Zaller, 2003: 112). At least for the next fifty years or so elections were not 'viewed as occasions for informed deliberation' (Zaller, 2003: 112). It was mainly partisanship that defined the relevant citizen role in the context of elections. During and towards the end of the 1800 s newspapers became available for a much larger part of the electorate, but, even then, Zaller claims, their main aim was to mobilize along party lines. As parties' role declined over the turn of the century however, there was a turn towards independent journalism, with a growing aim to report neutrally. Thus, the role of citizens also changed, from eager partisan, to independent thinker, who demanded pure facts from the journalistic institution, and then could make up a mind of their own, a development that took place in Europe in the 1970 s onwards.

It was in this context the full news standard emerged, where educated people could follow the main topics of the day. It is, however, worth recalling how the information available in the 1920 s probably was drastically different from our own time. One could make the argument that the amount of information available was of a relatively small size, actually making it possible for people to stay relatively well informed on the most important matters of the day. Today, the amount of information surpasses any human capacity for information processing, in a multi-flow, multi-media hybridized media landscape (Chadwick 2013). Zaller's argument is that critics of the modern news institution, who use the full news standard as their benchmark, do not take into account that this standard must be considered to be a historically situated norm, a norm that the society of today bears very little resemblance to. Thus, the criticism lingers on a norm and professional ideal that is impossible to live up to today, for both journalism and citizens. ${ }^{2}$ 
As an alternative to the full news standard, Zaller proposes a new standard, based on Schudson's ideal of a monitorial citizen. Zaller calls this standard the burglar alarm. The burglar alarm standard of news quality takes into account that, in today's society, knowledge within sub-fields has become highly specialized. Thus, the cognitive capacity of the human mind means that the ideal of being fully informed must be left behind, as people have to 'make do with satisficing, heuristics, and similar effort-saving techniques' (Zaller, 2003: 119). This standard should lead journalists to, in Zaller's words, 'cover non-emergency, but important issues by means of coverage that is intensely focused, dramatic, and entertaining' (Ibid.: 122), a popularized, more active journalistic style (see also Deuze, 2005; Sparks \& Tulloch, 2000; Van Zoonen, 2005). The burglar alarm metaphor becomes relevant as such news coverage, according to Zaller, should 'penetrate every corner of public space so few could miss it' (Zaller, 2003: 122).

Media hypes can be one possible effect of a news journalism operating by this standard. The burglar alarm further lingers on what Zaller refers to as positive media frenzies, characterized by intense and dramatic stories that saturate media coverage between different outlets and formats, and are suited to 'break the fog of disjointed news' (Ibid.: 121) and to engage the public. An argument against Zaller's new ideal (that, according to Bennett, (2003) is already a reality) is that it will lead to prioritization of news stories that are dramatic; that it takes a spectacular single event as a starting point; and that it focuses on strong stories with a clear protagonist. This was indeed the case in the media hype discussed in the following sections of this chapter. In this hype, the media's human-interest framing and repeated criticism of the government and immigration authorities make it an illustrative case for discussing how the audience reacts to and evaluates media hypes during the peak of the coverage, adding to the research regarding how audiences evaluate the results of a coverage adhering to the principles of a burglar alarm standard. In the next sections, we will discuss how the public views such coverage, as we report findings from a case study of one real-life media hype. ${ }^{3}$

\section{Public opinion concerning media hypes ${ }^{4}$}

Scholars will no doubt continue the normative debate on what constitutes good enough news and well-informed citizens also in the future. In the context of media hypes and public opinion, however, it is not irrelevant what publics themselves think about news coverage that satisfies most of the criteria for a 
media hype. In this section, we therefore report and discuss some of the findings from a study that analysed a media hype (content analysis of mainstream media during the hype), as well as public opinion (a representative survey conducted immediately after the hype had ended). The survey consisted of both closed and open-ended items, including relevant background and control variables, as well as respondents' evaluations of the involved actors, the media included. Before we discuss the findings from this survey, we briefly introduce the case that developed into a massive media hype.

\section{The case}

Madina Salamova, alias 'Maria Amelie', was a young female immigrant who became the public voice of irregular immigrants through her autobiography Illegally Norwegian published in 2010. Maria Amelie and her parents applied for asylum in Norway in 2002 when she was seventeen years old. The application was denied, and the family had been living illegally in Norway since 2003. Maria Amelie's arrest in January 2011 and her subsequent deportation to Russia caused massive protests, unprecedented media coverage, open conflict within the coalition government, and, consequently, change to the national immigration legislation (labelled 'Lex Amelie').

Maria Amelie was presented as an idealized, deserving media victim. Firstly, she was a fairly known face. In contrast to the non-personified, masses of denied asylum seekers, who are deported from Norway every day, she had published a book about being an irregular immigrant and had become a public face for an ongoing campaign to improve rights for irregular immigrants through public talks and media interviews. She was vulnerable. Maria Amelie was a young, fair-skinned female, and she thus easily evoked empathy and a supposed need for protection. As demonstrated in the literature on mediated 'victims' (Höijer, 2004; Horsti, 2013; Moeller, 2002), women and children are regarded as the most vulnerable and 'worthy' victims. Third, she was a hardworking, self-made success. Although she had been living in hiding, she had managed to complete an MA, had secured an internship with the national oil company, and had managed tours and music festivals. Against all odds, she was the personification of an immigration success story: fluent in Norwegian, well educated and hardworking, and possessing several attractive job offers. Finally, she was relatively better connected compared to other irregular immigrants (Ihlen \& Thorbjørnsrud, 2014) and had established an impressive personal network of intellectuals, writers, journalists, and activists through her work, voluntary work 
and activism. After twelve intense days, a devastated Maria Amelie was deported to Moscow on 24 January, but was able to return as a legal expert work migrant on 16 April of the same year. ${ }^{5}$

\section{The case turns into a media hype}

The Maria Amelie story was covered intensively in Norwegian news media, and a content analysis ${ }^{6}$ of the six most important national newspapers and two TV channels, showed that during the twelve days from Maria Amelie's arrest to her deportation these national newspapers published 405 articles, an average of thirty-three small and large articles every day, and the two TV channels aired no less than seventy news items in the same period, making the story one of the most covered issues in Norway in modern times. The key event that set off the media hype occurred when Maria Amelie was arrested by five police officers after giving a public speech based on her book. The arrest caused massive criticism, sparked unprecedented media attention, and dominated news headlines throughout the twelve-day period (Beyer \& Figenschou, 2012). When she was arrested, the broad network of NGOs behind the ongoing No one is illegal campaign, numerous student organizations, artists, and intellectuals, mobilized on social media platforms, organized demonstrations, and criticized the government in the media (Ihlen, Figenschou \& Larsen, 2015). Maria Amelie's network of asylum advocates and media professionals had greater media access and higher media competence compared to the supporters of other irregular immigrants. In particular, her boyfriend at the time, working as an assistant in the op-ed section at the leading leftist daily, tirelessly defended her case and acted as her spokesperson when she was detained. Her advocates employed well-documented strategies in their campaign to let her stay in the country (Ellermann, 2006; Every \& Augoustinos, 2008). They foregrounded similarities between her and other Norwegians and de-ethnicized (Horsti, 2013) her public image. Thus, the story is a typical example of the man-against-the-system narrative (Johnson-Cartee, 2005), frequently used in Western news media coverage of immigration ${ }^{7}$ (Ihlen \& Thorbjørnsrud, 2014). During the news hype, the in-depth, dramatic coverage of Maria Amelie's story seemed to be sufficient for the media, which did not expand its coverage beyond the key storyline. The content analysis of the coverage showed that it was almost exclusively framed as a human-interest story, focusing on the drama of the unfolding events, zooming in on the one chosen individual, and portraying her struggle in a highly emotional manner. ${ }^{8}$ 
The coverage was thus very similar to Vasterman's definition of a media hype, with a 'sudden materialization of a news wave' (Vasterman, 2005: 515) that arose quickly and then faded away. Media hypes are characterized by a coverage that is disproportionate to the relevance of the key event but, when established, it feeds itself and develops a life of its own (Ibid.: 509). To some extent, the case triggered a broader debate, as one third of the news items included substantial information about the issue of irregular immigration in general (definitions, statistics, living conditions, etc.), but only five per cent of the coverage was solely thematic. Second, the 'interaction between the media and social actors' (the campaign and her supporters) led to increased coverage of both social action and the reactions from social actors (Ibid.: 516). Where the Maria Amelie coverage differed substantially from Vasterman's (2005) definition, however, was the lack of comparable incidents and related news to the key event, as the media remained primarily focused on her story. As the story gained importance, other irregular individuals and rejected asylum seekers were introduced in about five per cent of the newspaper articles and seventeen per cent of the television coverage. Even though the stories of these individuals were as dramatic and strong as the Maria Amelie story, however, the media presence of the other immigrant individuals was ephemeral as they only appeared in the news once or twice (Beyer \& Figenschou, 2012). The primary media narrative, and subsequently also public debates, statements and political claim of supporters, focused on the 'exceptional' case rather than the larger group of irregular immigrants (Ihlen, Figenschou \& Larsen, 2015).

\section{Assessments of media performance compared with other involved actors}

A large part of the coverage of this particular case was concerned with repeated criticism of the government and immigration authorities, by the media as well as by other social actors that were quickly included in the media hype. This makes it an illustrative case for discussing how the audience reacts to and evaluates media hypes during the peak of the coverage. Against this background, we first asked how respondents evaluated the performance of key actors/institutions in the case, including the media?

Evaluation of performance concerning the issue was first measured with a closed item that asked respondents to state how well different actors had performed, from 1 (very badly) to 5 (very well). As mentioned above, the government received a lot of criticism in the media during the news 
serial, but it was regarded as the institution that performed best in the survey, with a mean score of 3.1. Overall, the government was the only actor that averaged more positively than negatively in audience evaluations of performance. Also, the immigration administration and the police, the institutions responsible for the arrest of Maria Amelie and the resolutions leading to her arrest and deportation, were criticized quite harshly in the media. The audience, however, gave them both a mean score of 2.9 on how well they had performed concerning the case. The political opposition, while quite invisible in much of the coverage, received a mean score of 2.9. ${ }^{9}$ The media were evaluated as having the lowest performance, with a mean score of 2.5 . This indicates how many members of the audience were indeed quite critical of how the media covered the issue and the prioritization that was given by the media when it comes to coverage of the issue. We further explored who were most critical of the media and how different background variables might explain the variation when it comes to respondents' evaluation of the media. Audience members' use of the media could be thought of as a key variable, as increased exposure to news media might contribute to some sort of fatigue over the extensive coverage. We constructed a regression model to explore this further and also added other relevant background variables such as gender, age, education, and attitude towards immigration (see Beyer \& Figenschou, 2014: 1953 for regression model). All the standard variables showed a significant contribution to the model, but none of the media-use variables produced significant effects: Women were more positive about media performance than men. Older people were also more positive. People with a stricter attitude to immigration were more negative towards the media than people with a more liberal view. Respondents with higher education were also more negative towards media performance. In essence, the audience was more critical about the media than other involved parties, but there is no sign that this critical attitude had much to do with the level of media use. It is interesting that we see no effect of media use, as one could expect those more exposed would grow more tired of the issue. That said, media use does not necessarily equate with issue exposure in this case. This issue was everywhere for the two weeks the hype lasted, and even media users with low use would almost certainly encounter this story several times as it dominated headlines in TV news, newspapers, and online news, as well as in debate programmes and online discussion forums.

The respondents' attitudes towards immigration need some further elaboration: One of the important references that the media made in the early days of the coverage of the case was that the government and the 
immigration authorities were out of step with the general public opinion. The media made reference to various demonstrations and media-initiated surveys ${ }^{10}$ that allegedly showed that a majority supported Maria Amelie and wanted her to be allowed to stay in the country. It should, however, be noted that after only a few days there was a swing in public opinion, and more people then said that she should not be granted permission to stay in the country, a view more in line with public opinion on immigration policy in general. ${ }^{11}$ This might be understood in terms of some kind of adjustment; when the story broke in the media, many people instinctively reacted with sympathy towards the woman, but as people had more time to learn about the case they might have seen the need to adjust their standpoints. For partisans with a fairly restrictive view on immigration in the survey, we find evidence of a form of the hostile media phenomenon (Vallone et al., 1985), as they rate the media more harshly than others with different views on immigration. We also see that those respondents planning to vote for either the right-wing Progress Party or the Labour Party view the media more critically than other voters. The Norwegian Progress Party has had a clear issue ownership and a strict policy on immigration issues, and the Labour Party was the main government party at the time, which also held certain issue ownership and had been quite strict on immigration (Karlsen \& Aardal, 2011). Finally, we find that respondents who wanted Maria Amelie to stay in the country were much more positive in their evaluation of media performance than those who wanted her to leave: Among those who wanted her to stay, two thirds were either positive (one third) and neutral (one third) in their evaluations of media coverage, in contrast to those in favour of evicting her, over seventy per cent of whom were critical of the role played by the media (see Beyer \& Figenschou 2014: 1954, Figure 11.1 for details).

\section{Scale, scope, and biased media}

One body of literature claims that a highly dramatic, intense, and sensational coverage is what is needed to get people interested in political matters and that the human-interest frame may contribute to increased political knowledge among disinterested members of the public (see, among others, Jebril et al., 2013; Van Zoonen, 2005; Zaller, 2003). Here we have a potent example of such coverage, and we also have respondents' own evaluations of and comments on this coverage as it peaked in the media. When evaluating the media's performance, we first ask if people are mainly critical, neutral, or positive in their evaluations of the media's performance? Second, we look 
more into what aspects people highlight as most important in their evaluations of media performance. Here we emphasize how the audience reacts to and evaluates a real-life media hype played out in the media, and we aim to go beyond the studies that explore how frames are mirrored in respondents' thoughts (Price et al., 1997; Valkenburg et al., 1999), by explicitly asking respondents to evaluate the coverage in their own words.

As demonstrated above, many respondents are fairly critical of the coverage. About two thirds of the respondents were critical of the coverage on a general level, seventeen per cent were coded as neutral evaluations, and thirteen per cent were coded as giving mainly positive evaluations when they formulated their view of the media coverage in their own words. As a final step, we will look into what people were critical about and what they thought of as positive with regards to the media coverage. These are the aspects of the media coverage that the respondents mentioned when asked to write their views on the media coverage of the case. The respondents were not given any keywords, or guided on what to emphasize in their evaluations; in other words, these evaluations were the first that came to their mind, and thus, arguably, the most salient aspects in their evaluations.

The clearest criticism of the media is the volume of the coverage. Analysing the responses, we find that almost half of the respondents formulate a critique regarding the scale of the coverage. Without being asked to state anything about the scale, they say that the coverage was too extensive - that there was too much coverage altogether. This is the clearest and most specific evidence of a critique of the hype that developed during the two intensive weeks. However, it also points to an implicit critique of the human-interest framing, as the story was entirely framed within the human-interest frame, a point substantiated by the other aspects of the criticism, discussed below.

The respondents also referred to the scope of the coverage, in this case particularly to how this single case was used. Thirteen per cent of respondents stated they were critical of the use of this single case, often by juxtaposing it to other relevant immigrant cases, or even to the more general issue concerning irregular immigration. While this may not seem a very large proportion, we must keep in mind that the respondents were not given any keywords to focus on in their evaluations.

The last main finding from the open item was related to the belief that the media operate with some kind of bias. While it is not a new finding that the public has opinions about media bias, it is notable that as many as one in five stated that the media were biased in this case. The reason for this finding may be due to several factors. The media received criticism during 
the coverage for taking sides on the issue, and some respondents may have picked up this criticism. It is also probable that the scale of the issue may have led to this kind of criticism, as the amount of coverage was so large that it led to decreased coverage of other issues. Lastly, the concept of bias may be an inherent effect of human-interest coverage in itself, because the way such framing works makes it harder to cover individuals in a balanced way (Benson, 2013; Steimel, 2010). The concept of bias is also related to the aforementioned hostile media phenomenon, and, in this case, where there are signs of an unbalanced coverage, we might have observed the relative hostile media effect that can be observed when respondents are given strongly slanted stories (see Gunther, Christen, Liebhart \& Chia, 2001 for a study on unbalanced news content). Moreover, ten per cent of the respondents reacted to the sensationalist and emotional media coverage of the Maria Amelie story. Only a very small minority stated that they were satisfied with the media coverage in the open-ended question (two per cent).

\section{Discussion and conclusion}

So, what does this contribute to our understanding of media hypes and public opinion? The notion that audiences are critical towards the news and even view the news as biased is not novel (Cappella \& Jamieson, 1997: 209-213). However, in the context of media hypes, and with the perspectives of the full news standard and the burglar alarm standard present, it must be noted that our findings suggest that public opinion is more in line with the former than the latter when asked to evaluate what was quite clearly a media hype. ${ }^{12}$ This holds even for respondents that were sympathetic to the case itself and supported Maria Amelie's right to stay in the country. In the following section, we provide several tentative explanations for this situation, based on the respondents' own qualitative evaluations of media performance. ${ }^{13}$

\section{The exhausted public}

This explanation points to several factors that are due to the massive coverage as well as the fact that some of the media, arguably, were slanted in their coverage of Maria Amelie. First, due to the massive, almost repetitive coverage, many people may have experienced some sort of compassion fatigue (Moeller, 1999). This may partly involve the human-interest framing of the story, and partly the fact that it became a media hype. Almost half 
of the responses stated that the coverage had got out of hand regarding the sheer scale of it all. As one respondent put it: 'It was too intense; we lose interest and get bored of it all' (Resp. no. 541). Elaborating further, others offered explanations to why the media might have behaved like they did: 'It is overexposed - they made a mountain out of a molehill. It's easy for the media to portray one sweet, young girl as a victim. It's a good story. It sells newspapers and attracts viewers' (Resp. no. 75).

Both these responses clearly criticize the hype aspect of the case. Also, the notion of a burglar alarm standard, operating by creating positive frenzies of coverage that no member of the public can miss, seem to become tiring for these respondents. Steimel (2010) also notes that the human-interest frame itself may lead to evaluations that imply that the media does not fulfil its role as an objective party, because other perspectives than the ones pertaining to the case itself in many cases are downplayed. Regarding the media hype explanation, the massive coverage might have led people to view the issue as slanted and to feel the scale of coverage got out of hand. Respondent no. 434 puts it like this: 'Completely hopeless. [The media] are sensationalist, they downplay the facts, and they play on emotions in one individual case without conveying the wider consequences of changing the law'. This view of the media as biased was not uncommon among respondents. Both the widespread use of the human-interest frame and the scale of the coverage might have contributed to this, but one should not neglect the fact that parts of the media coverage also discussed possible bias in the media (so-called meta-debate) during the intense twelve days the story lasted.

\section{Public opinion was misunderstood by the news media}

The critical evaluations of the media may imply that the perceived public support for Maria Amelie, frequently reported in much of the early coverage of the issue, may have been a misrepresentation by the media. From the content analysis we know that media elites such as in-house analysts/commentators, the editors, and the most profiled reporters, were very critical of the authorities' handling of the case. This criticism dovetailed with a broader criticism of the Norwegian government at the time - that it had become distanced from the public and did not understand its popular foundation. The sentiments represented by vocal media elites, and others who were personally involved in the story, might thus have overemphasized how broad and deep this condemnation was and how representative it was of public opinion. Perhaps it was the 'chattering classes' (the media elites and the cultural elites) that were out of touch with the people, not the 
immigration authorities. Several respondents also seem to acknowledge a view that the media was out of touch with a volatile public opinion in these matters. Respondent no. 487 put it like this: 'The media coverage was exaggerated and biased. First everyone sympathized with her, and then they turned against her. The fifty other Russian asylum seekers that were deported were only mentioned in one, tiny news brief'.

\section{The timing of the survey}

Finally, it is worth considering the timing of the survey. While support for Maria Amelie was probably higher in the early stages of the coverage, it was probably at its lowest in the first days after she had been sent back to Russia. Maria Amelie and her supporters had repeatedly warned that it would be dangerous for her to go back to Russia. Whenever she was asked about Russia in interviews, she fought back tears and stressed how terrified she was to be sent back. However, when she was sent out of the country, there were journalists on the airplane with her, and more journalists met her in Moscow. In the following days she and her boyfriend were interviewed on the streets and cafes of Moscow, often in a joyful mood, and there was little evidence of this being a particularly dangerous location for her. Thus, some members of the audience may have felt that they had been manipulated. Some of the respondents might also have been influenced by the coverage following her deportation to Russia. Respondent no. $55^{8}$ voices a quite critical opinion: 'Exaggerated! One-sided. It was portrayed as if the migration authorities are incompetent and stupid, when they have in fact treated her case fairly [...] They have portrayed Maria as incredibly sweet and sympathetic, and I doubt she is [...]'

\section{Limitations and future research}

The case of Maria Amelie provided an excellent opportunity to perform an investigation into how the public evaluates media hypes. The story turned into an example of media hype that has few parallels in Norwegian media when it comes to the amount and intensity of the coverage. At the same time, the individual-against-the-system story represents a recurrent, frequently used script in the coverage of immigration both in Norway (Ihlen \& Thorbjørnsrud, 2014) and internationally. However, the unique characteristics of this study also pose some limitations for generalization. In the following we address these limitations and suggest how future research may try to disentangle the effects of human-interest framed media hypes. 
First, the use of a single-case approach can never lead to generalizations to a broader population. What these extreme cases can do is to make the mechanisms involved in cases of media hype more clear. In the case reported here, the inability of the media to move beyond the human-interest frame makes an interesting contribution that should be explored further. As we note below, what should be addressed in future research is how one should disentangle the different effects of media hype, framing, and the nature of the case itself.

Second, the public opinion data used in the study is cross-sectional, and a follow-up study to check whether attitudes were long-term or rather more ephemeral was not possible to perform. Since the evaluation of media hypes should be studied in a real-life context, making experiments more difficult (but by no means impossible), the desired design could have involved a follow-up survey, either with a sample of the same respondents, making it a panel study, or by performing a new survey altogether. However, the time frame and economic considerations made such endeavours impossible at the time. Future research should definitely try to employ some sort of longitudinal perspective to the study of evaluations of real-life media hypes.

Third, as the hype was laden with a human-interest narrative, it proved hard to disentangle the effects of the hype itself and the framing of the story. The data suggest, however, that it was the volume of coverage that was the main reason for people's negative impressions of media performance. We have reason to believe that it was indeed the powerful combination of the hype and the human-interest framing that caused such critical evaluations, but the design does not allow us to conclude on this point. Later studies should try to disentangle these effects by providing stimulus materials in controlled experiments that make us able to obtain a clearer view of what actually happens when people evaluate coverage that involves media hype.

\section{Notes}

1. Note: An earlier version of this study was published as 'Human-interest fatigue: Audience evaluations of a massive emotional story', International Journal of Communication, 8 (2014): 1944-1963. The study was part of an international research project, Mediation of Migration (University of Oslo, 2011-2014), where Beyer and Figenschou were postdoctoral fellows.

2. See Waisbord (2012), among others, for a comprehensive discussion of professional journalism, professional ideals and professional codes of conducts. 
3. We argue that a real test of how public opinion views media hypes needs to be conducted in a real-life context. Of course, valuable insight might also be provided from more general survey items on what people would like journalism to be. However, a salient example of a real-life exemplar of a media hype as the one reported here is preferred.

4. The empirical evidence is largely based on Beyer and Figenschou (2014). Information about methods and measures relating to the data and the analyses can be found by consulting this earlier work.

5. The government and immigration authorities firmly and repeatedly stressed that the family had been treated correctly according to the law, that the decision was irreversible, that the law is equal to everyone, and that Maria Amelie had to return to Russia. Behind the scenes, however, the coalition government pushed to change the national immigration legislation on skilled expatriate workers (people with expert competence, who already have a job offer and are in possession of the correct identity papers), making it possible for Maria Amelie to apply for a work permit once she got her papers.

6. The content analysis was performed by manually checking all the relevant national and regional media in from Maria Amelie's arrest, to her final deportation to Russia. Basic variables such as outlet, format (news/op ed.), length, quoted sources and their affiliations were mapped. Further, we coded for the presence/absence of several aspects of the human-interest frame (focus on the individual case; focus on feelings; visual information pertaining to the individual case; personal or private information about the individual [beyond information directly relevant to the case]) (see Beyer \& Figenschou (2014) for more details regarding method).

7. As a result of massive media coverage, a selected few idealized victims occasionally become national icons (Rosello, 1998). These high-profile cases such as the American stories of Elian Gonzalez (1999-2000), Elvira Arellano (2007), and Jose Antonio Vargas (2011), the Maria Amelie story in Norway (2011), and the 'sans papiers' protesters (1996) in France, receive massive coverage over limited periods of time, helped by different types of support groups and networks.

8. About one in five news items were very emotional, one in five included highly emotional images and one in ten included private information about Maria Amelie (Beyer \& Figenschou, 2012).

9. It should be noted that the distribution of answers on the opposition variable was very different from the other actors, as almost half the respondents selected neither good, nor bad (3).

10. In an opinion poll for the largest popular newspaper $(V G)$, conducted by InFact on 15 January 2011, sixty-one per cent stated that Maria Amelie should be allowed to stay in the country, whereas twenty-seven per cent wanted her deported to Russia.

11. On 21 January, InFact conducted a follow-up poll in which forty-eight per cent argue she should be deported and forty per cent support her right 
to stay in the country. These findings are highlighted as 'the people have turned against' Maria Amelie.

12. The media hype discussed in the previous sections was also, we would argue, a key example of journalism operating by a burglar alarm standard.

13. It should be noted that we are concerned with the critical opinions here, and that several respondents also voiced supportive opinions of both Maria Amelie and the media coverage.

\section{References}

Bennett, W. Lance (2003). 'The burglar alarm that just keeps ringing: A response to Zaller'. Political Communication, 20 (2), 131-138.

Benson, Rodney (2013). Shaping immigration news: A French-American comparison. Cambridge: Cambridge University Press.

Beyer, Audun \& Tine U. Figenschou (2012). 'It's what the audience wants? Public opinion on an emotional, dramatic and massively covered news story'. Paper presented at ECREA, Istanbul (October 2012).

Beyer, Audun \& Tine U. Figenschou (2014). 'Human-interest fatigue: Audience evaluations of a massive emotional story'. International Journal ofCommunication, 8, 1944-1963.

Cappella, Joseph N. \& Kathleen H. Jamieson (1997). Spiral of cynicism: The press and the public good. New York: Oxford University Press.

Chadwick, Andrew (2013). The hybrid media system: Politics and power. Oxford: Oxford University Press.

Cho, Seung Ho \& Karla K. Gower (2006). 'Framing effect on the public's response to crisis: Human interest frame and crisis type influencing responsibility and blame'. Public Relations Review, 32 (4): 420-422.

Christians, Clifford G., Glasser, Theodore L., McQuail, Denis, Nordenstreng, Kaarle Nordenstreng \& Robert A. White (2009). Normative theories of the media:Journalism in Democratic Societies. Urbana \& Chicago, IL: University of Illinois Press.

Deuze, Mark (2005). 'What is journalism: Professional identity and ideology of journalists reconsidered'. Journalism, 6 (4): 442-464.

Ellermann, Antje (2006). 'Street-level bureaucracy? How immigration bureaucrats manage public opposition'. West European Politics, 29 (2): 287-303.

Every, Danielle \& Martha Augoustinos (2008). “Taking advantage' or fleeing persecution? Opposing accounts of asylum seeking'.Journal of Sociolinguistics, 12 (5): 648-667.

Gunther, Albert, Christen, Cindy, Liebhart, Janice \& Stella Chia (2001). 'Congenial public, contrary press, and biased estimated of the climate of opinion'. Public Opinion Quarterly, 65 (3): 295-320. 
Höijer, Birgitta (2004). 'The discourse of global compassion: the audience and media reporting of global suffering'. Media, Culture \& Society, 26 (4): 513-531.

Horsti, Karina (2013). 'De-ethnicized victims: Mediatized advocacy for asylum seekers'. Journalism: Theory, Practice \& Criticism, 14 (1): 78-95.

Ihlen, Øyvind \& Kjersti Thorbjørnsrud (2014). 'Making news and influencing decisions: Three threshold cases concerning forced return of immigrants'. European Journal of Communication, 29 (2): 139-152.

Jebril, Nael, De Vreese, Claes, Van Dalen, Arjen \& Erik Albæk, (2013). 'The effects of human interest and conflict news frames on the dynamics of political knowledge gains: Evidence from a cross-national study'. Scandinavian Political Studies, 36 (3): 201-226.

Johnson-Cartee, Karen S. (2005). News narratives and news framing. Oxford: Rowman \& Littlefield.

Karlsen, Rune \& Bernt Aardal (2011). 'Kamp om dagsorden og sakseierskap [Agenda-setting and issue ownership]'. In: Bernt Aardal (ed.), Det politiske landskap: En studie av stortingsvalget 2009 [The Political landscape: A study of the parliamentary elections in 2009], 131-162). Oslo: Cappelen Damm.

Moeller, Susan D. (1999). Compassion fatigue: How the media sell disease, famine, war and death. New York: Routledge.

Moeller, Susan D. (2002). 'A hierarchy of innocence: The media's use of children in the telling of international news'. The Harvard International Journal of Press/ Politics, 7 (1): 36-56.

Price, Vincent, Tewksbury, David \& Elizabeth Powers (1997). 'Switching trains of thought: The impact of news frames on readers' cognitive responses'. Communication Research, 24 (5): 481-506.

Rosello, Mireille (1998). 'Representing illegal immigrants in France: From clandestines to l'affaire des sans-papiers de Saint-Bernard'. Journal of European Studies, 28 (xxviii): 137-151.

Schudson, Michael (1998). The good citizen. A history of American civic life. New York: The Free Press

Sparks, Colin \& John Tulloch (eds) (2000). Tabloid tales - Global debates over media standards. Oxford: Rowman and Littlefield.

Steimel, Sarah J. (2010). 'Refugees as people: The portrayal of refugees in American human interest stories'. Journal of Refugee Studies, 23 (2): 219-237.

Valkenburg, Patti M., Semetko, Holli A. \& Claes H. de Vreese (1999). 'The effects of news frames on readers' thoughts and recall'. Communication Research, 26 (5): 550-569.

Vallone, Robert P., Ross, Lee \& Mark R. Lepper (1985). 'The hostile media phenomenon: Biased perception and perceptions of media bias in coverage of the Beirut massacre'.Journal of Personality and Social Psychology, 49: 577-585. 
Van Zoonen, Liesbet (2005). Entertaining the citizen: When politics and popular culture converge. Lanham, MD: Rowman \& Littlefield.

Vasterman, Peter (2005). 'Media-hype: Self-reinforcing news waves, journalistic standards and the construction of social problems'. European Journal of Communication, 20 (4): 508-530.

Zaller, John (2003). 'A new standard of news quality: Burglar alarms for the monitorial citizen'. Political Communication, 20 (2): 109-130.

\section{About the authors}

Audun Beyer is a Senior Research Fellow at the Institute for Social Research in Oslo. He received his PhD from the University of Oslo in 2012 on the topic of news coverage of elections. His research interests are political communication, news framing, empirical research methods and public opinion formation. His research is published in international journals including Communication Research, The International Journal of Press/ Politics, and Scandinavian Political Studies. He has received awards from the International Communication Association (ICA) and the Association for Education in Journalism and Mass Communication (AEJMC).

Tine Ustad Figenschou is Associate Professor in Media and Communication at Oslo and Akershus University College, Oslo. Her research interests include media and marginalization, government communication, mediatization processes, journalism and political communication. She has published widely in international journals, including The International Journal of Press/Politics; Media, Culture \& Society; Journalism Studies; Journalism, and is the author of 'AlJazeera and the global news landscape: The South is talking back' (Routledge, 2013). 